\title{
ŽENE NA RUKOVODEĆIM RADNIM MJESTIMA U ODABRANOJ ŽUPANIJI
}

\author{
Rudi Štekl, struč. spec. oec., pred. \\ Europska poslovna škola Zagreb \\ Selska cesta 119, 10110 Zagreb, Hrvatska \\ Telefon: +38591 4400 184, email: rudi.stekl@ebus.hr
}

\section{SAŽETAK}

Položaj žena na rukovodećim pozicijama u državnom, ali i u privatnom sektoru dobiva sve veću važnost na tržištu rada u Republici Hrvatskoj. Pojam "stakleni strop" koji se koristi kada se govori o sprječavanju napredovanja žena na više hijerarhijske razine na određenom radnom mjestu dobiva sve veću zastupljenost kao važna tema. Glavni cilj ovoga rada je prikazati razinu položaja žena odnosno zastupljenost istih u jedinicama lokalne samouprave kroz istraživanje anketnog upitnika na uzorku od 60 gradskih službenika odabrane županije. Ovakav model ili tzv. fenomen ženskog spolnog diskriminiranja posebno dominira u jedinicama lokalne i regionalne samouprave gdje nedovoljna inkluzija ženskih osoba u politički spektar posljedično dovodi do lošijeg radnog statusa i nemogućnosti profesionalnog napredovanja. lako zakon o ravnopravnosti spolova zabranjuje spolnu diskriminaciju na radnom mjestu, još uvijek „stakleni strop“ blokira napredovanje žena na najviše položaje u sustavu jedinica lokalne samouprave. Ostali ciljevi rada su identifikacija prepreka u napredovanju žena na organizacijskoj ljestvici te predložene preporuke u poboljšanju razvoja karijere žena u navedenom sustavu. Iz dobivenih rezultata istraživanja u radu prikazane su i spoznaje do kojih se došlo. Uloga i značaj ovakvih problematika u društvu sve je više izražena upravo u vidu potreba tržišta odnosno inkluzije cijelog društvenog spektra. Društvo određuje svoju budućnost te razinu napredovanja u kojem bi svi trebali imati jednaka prava i mogućnosti neovisno o spolu, dobi i rasi!

Ključne riječi: stakleni strop; položaj žena; jedinice lokalne samouprave 


\section{UVOD}

Položaj žena i njihov ravnopravni položaj na radnim mjestima prvenstveno je određen zakonom o ravnopravnosti spolova u Republici Hrvatskoj. „Ravnopravnost spolova znači da su žene i muškarci jednako prisutni u svim područjima javnog i privatnog života, da imaju jednak status, jednake mogućnosti za ostvarivanje svih prava, kao i jednaku korist od ostvarenih rezultata" (Zakon o ravnopravnosti spolova, 2017). U radu je analiziran hijerarhijski položaj ženskih osoba na tržištu rada u odabranoj županiji. Osnovna svrha rada je prikazati razinu položaja radnog mjesta žena u sustavu jedinica lokalne samouprave. Metoda koja je odabrana prilikom istraživanja anketni je upitnik na uzorku od 60 ispitanika 4 gradske uprave Vukovarsko - srijemske županije zbog dostupnosti ispitanika. Osnovni cilj rada i intencija istraživanja je utvrditi koje su to prepreke u napredovanju žena na više razine i koje su to spoznaje te prijedlozi rješenja koji bi pomogli u rješavanju ove problematike. Dobiveni su rezultati okvir i spoznaje iz kojih su doneseni konkretni zaključci te prijedlozi rješenja. Zadnjih nekoliko godina ova tema dobiva sve veću važnost zato što se situacija mijenja te je na rukovodećim pozicijama sve više osoba ženskog spola. Međutim, navedena radna mjesta su nažalost još uvijek često podložna političkom utjecaju što dovodi do negativnog deficitarnog omjera ženskih u odnosu na muške osobe. Ovakva situacija proizlazi i iz nedovoljne inkluzije političke aktivnosti ženskih osoba u političkom spektru pojedinog područja u kojem djeluju. „Uloga žena na tržištu rada postaje sve aktivnija na upravljačkim funkcijama te u poduzetništvu, kao i samozapošljavanju. Mijenjaju se i stavovi zaposlenika prema ulozi žene u poslovnim organizacijama tako da se prihvaća uloga žene u poslovnim organizacijama, jednako kao i uloga žene u obitelji“ (Leinert Novosel, 2004). Hrvatska se u ovome pogledu nastoji snažno razvijati prateći Europske trendove, ali na lokalnoj razini još smo uvijek ispod prosjeka. „Prema podacima The Female FTSE Board Reporta iz ožujka 2015. godine, najviše žena u upravama je u Norveškoj (čak 38,9 \%) te Finskoj (32,1 \%), Francuskoj (28,5 \%) i Švedskoj (27,5\%). Hrvatska je sa 16,3 \% po udjelu žena u upravama iza Njemačke (16,6 \%), ali ispred Austrije (10,7 \%), Luksemburga $(8,9$ \%) i Švicarske (13,9 \%)“ (Selectio.hr., 2016). lako je jedan od ključnih ciljeva Hrvatske i Europske unije ravnopravnost spolova iz gore navedenih podataka to nije razvidno. „Unatoč promjenama koje idu u pozitivnom smjeru zastupljenosti oba spola na upravljačkim pozicijama u organizacijama, daleko smo od pune ravnopravnosti spolova u poslovnim organizacijama. Još uvijek je prisutan tzv. stakleni strop u poslovnim organizacijama koji opisuje zapreke s kojima se suočavaju zaposlenici, a povezujemo ih s diskriminacijom prema spolu“ (Jalšenjak i Krkač, 2016). Kako bi se društvo razvijalo u cjelini potrebno je rušiti sve loše društvene barijere, odnosno prepreke, a pogotovo u polju spolne diskriminacije bilo kakvog tipa na tržištu rada.

\section{OBJAŠNJENJE POJMA „STAKLENI STROP“}

„Pojam „stakleni strop“ ili tzv. nevidljiva barijera nosi negativnu konotaciju zato što se radi o spolnoj diskriminaciji osoba ženskog spola na radnim mjestima na više vodeće i rukovodeće razine" (Vidaček-Hainš, 2011). Osnovna intencija ovog rada bila je utvrditi koliko osoba ženskog spola ima na mjestima pročelnika/ica odjela u gradskim upravama odabrane županije. „Stakleni strop sprječava pojedince, pripadnike podzastupljenih skupina, 
kao što su pripadnici nacionalnih manjina ili rodno podzastupljeni, da dosegnu rukovodeće pozicije u poslovanju“ (Smith, Caputi, Crittenden, 2012). Današnjom brzo transformacijom i dinamičnim razvojem društva mijenjaju se trendovi u svim njezinim segmentima, a pogotovo u polju spolne ravnopravnosti. Položaj žena koje pokušavaju ravnopravno sudjelovati na svim višim razinama odlučivanja u privatnom i državnom sektoru se mijenja, a s time se mijenja i cjelokupno društvo. Sposobnost, kvalifikacija, znanje i ambicija ženskih osoba nikad nije bila upitna, razlog neostvarivanja viših pozicija i neravnopravnosti leži u dodjeljivanju ovakvih pozicija muškim osobama. Kada je riječ o istraživanju koje je ovdje provedeno radi se o muškom političkom spektru lokalne i regionalne zajednice. „Žene i muškarci ostvaruju podjednake rezultate na financijskom planu, jednako se suočavaju s poslovnim izazovima i jednako implementiraju ciljeve dugoročnog strateškog razvoja organizacije. Međutim, žene su uspješnije na području upravljanja ljudskim potencijalima i više rade na osobnom razvoju, za razliku od muškaraca koji su uspješniji kada je riječ o profesionalnom napredovanju“ (Deloitta, 2013). „Stakleni stop“ je loša nevidljiva barijera koju svako društvo mora razbiti kako bi ravnopravnost bila jednaka, a društvo krenulo prema naprijed.

\section{MOGUĆNOSTI NAPREDOVANJA ŽENA U REPUBLICI HRVATSKOJ}

Teorijski okvir pokazuje da je „sudjelovanje žena na tržištu rada u stalnom povećavanju tijekom prošlog i ovog stoljeća. Taj proces nažalost, nije značajnije promijenio nekoliko parametara, a to je udio žena na rukovodećim pozicijama, bolje plaćenim djelatnostima te broju nezaposlenih" (Vučemilović, 2011). Jedan od najčešćih oblika diskriminacije na tržištu rada su razlike u plaćama koje su uzročno povezane za višim rukovodećim pozicijama, a na koje osobe ženskog spola ne mogu tako lako doći. Dakle, kako bi onemogućili nečiji osobni i profesionalni razvoj u današnjem kapitalističkom vremenu dovoljno mu je onemogućiti veći financijski priljev sredstava. Žene u Republici Hrvatskoj imaju načelno prema zakonu jednake mogućnosti i prilike za napredovanje na svim razinama, ali u praksi, a pogotovo u ruralnim sredinama statistički podatci pokazuju drugačije. Razlog leži u činjenici da je na lokalnoj, ali i na nacionalnoj razini mali postotak uključenosti žena u političke sfere djelovanja. Zadnjih se godina ovakva praksa mijenja, ali još uvijek nedovoljno za ravnopravni položaj. „Žene puno bolje iskorištavaju prilike i šanse koje dobiju za školovanje ili za odrađivanje poslovnih zadataka, imaju više sluha za razumijevanje tuđih problema, ne teže stvaranju neprijateljskog poslovnog ozračja te lakše uvažavaju socijalne, rasne, kulturne i sve ostale posebnosti pojedinaca" (Avelini-Holjevac, Galičić, 2005). Republika Hrvatska je u ovom smislu izuzetno patrijarhalno društvo, žene su više usmjerene prema svom osobnom napredovanju, ulaganju u znanje, kvalifikaciju i obrazovanje dok su muškarci orijentirani prema osobnom profiliranju na političkoj sceni bilo ona lokalna, regionalna ili nacionalna. Ovakvim pristupom muškim osobama je brže i lakše omogućen dolazak te pozicioniranje na više rukovodeće funkcije, ali i visoke političke funkcije iz kojih opet „guraju“ svoje muške kolege na više rukovodeće funkcije. Novo dinamično vrijeme donosi nepredvidive trendove, a upravo se ženske osobe puno bolje snalaze u kriznim nepredvidivim situacijama zbog svoje urođene intuicije brzog adaptiranja i svladavanja problema. Uloga i značaj žena u poslovnom svijetu na sve višim razinama odlučivanja dobiva sve veću važnost i ovaj tzv. „nježniji spol“ polako postaje lider na tržištu rada, ali i na političkoj sceni Republike Hrvatske i Europske unije. 


\section{ANALIZA ISTRAŽIVANJA NA PRIMJERU ODABRANE JEDINICE LOKALNE SAMOUPRAVE}

Analiza istraživanja provedena je metodom „anketni upitnik“ ili kvantitativnom metodom. Uzorak online ankete čini 60 ispitanika četiri gradske uprave, gradski službenici grada Vukovara, Vinkovaca, Otoka i Županje. Anketa je provedena putem engl. „Google Forms" online softvera u razdoblju od 28.4. do 30.4. 2021. godine. Osnovna struktura pitanja bila su dihotomna pitanja (da/ne) i zatvorenog tipa (pitanja s višestrukim izborom), a dodatno je izrađen i prikazan postotak ženskih i muških osoba u odjelima gradskih uprava iz podataka sa službenih web stranica. Metoda je odabrana zbog dostupnosti ispitanika, a s obzirom na to da se trebalo doći do socio-demografskih karakteristika i stavova mišljenja zaposlenika u gradskim upravama, dakle specifično ciljane skupine. U tablici koja slijedi jasno je vidljiva struktura zaposlenih u gradskim službama prema spolu i dobi. U istraživanju je sudjelovalo 60 ispitanika, 25 osoba ili 41,66\% ženskog i 35 osoba ili 58,33\% muškog spola.

Tablica 1. Struktura ispitanika prema spolu i dobi

\begin{tabular}{lcc}
\hline & $\mathbf{N}$ & $\%$ \\
\hline Spol & & \\
a. M & 35 & $58,33 \%$ \\
b. Ž & 25 & $41,66 \%$ \\
Dob & & \\
a. 20 - 30 godina & 9 & $15,00 \%$ \\
b. 30 - 40 godina & 28 & $46,66 \%$ \\
c. 40 - 50 godina & 13 & $21,66 \%$ \\
d. iznad 50 godina & 10 & $15,66 \%$ \\
Ukupno & $\mathbf{6 0}$ & $\mathbf{1 0 0} \%$ \\
\hline
\end{tabular}

Izvor: rezultati istraživanja autora rada

U gornjoj tablici prikazana je dobna struktura ispitanika, kreće se u rasponu od 20 do iznad 50 godina. Najveći broj ispitanika, 28 ili 46,66\% pripada u kategoriju od 30 do 40 godina. $U$ skupinu 20 do 30 godina pripada 9 ili 15\%. U dobnu skupinu ili kategoriju iznad 50 godina spada 10 ili 15,66\%. U kategoriju 40 do 50 spada 13 gradskih službenika ili 21,66\%.

Sljedeća skupina pitanja koja je provedena u anketi odnosi se na stavove i mišljenja ispitanika o percepciji zaposlenih osoba na radnim mjestima u gradskim upravama odabrane Vukovarsko - srijemske županije. 
Tablica 2. Percepcija mišljenja ispitanika u gradskim upravama

\begin{tabular}{llc}
\hline R.br. Pitanje & DA & NE \\
\hline 1. Smatrate li da su muškarci na istoj poziciji bolje plaćeni od žena? & $61 \%$ & $39 \%$ \\
$\begin{array}{l}\text { 2. Mislite li da, ako ste član političke stranke da možete brže napredovati u } \\
\quad \text { gradskoj upravi? }\end{array}$ & $79 \%$ & $21 \%$ \\
3. Ženama se prilikom zapošljavanja postavlja pitanje o braku i djeci? & $52 \%$ & $48 \%$ \\
4. Rukovodeće pozicije u gradskim upravama namijenjene su muškarcima & $59 \%$ & $41 \%$ \\
\hline
\end{tabular}

Ukupno: 60 ispitanika

Izvor: rezultati istraživanja autora rada

Iz tablice 2. vidljivo je da $61 \%$ ili 37 od ukupnog broja 60 ispitanika smatra da su muškarci na istoj poziciji bolje plaćeni od svojih ženskih kolega dok je njih 39\% ili 23 odgovorilo da ne smatra da su muškarci bolje plaćeni. Iz iste tablice je vidljivo da u visokom postotku od 79\% ili 47 ispitanika smatra da ako ste član političke stranke da možete brže napredovati u gradskoj upravi. Samo njih $21 \%$ ili 13 smatra da ovo nije pravilo. Ispitanici u postotku od 52\% ili 31 navode da se ženama postavlja pitanje o braku i djeci prilikom zapošljavanja, 48\% ili 29 smatra da to nije tako. Posljednje pitanje koje je navedeno u tablici odnosi se na ključno pitanje, jesu li rukovodeće pozicije u gradskim upravama namijenjene muškarcima, 59\% ili 35 izjašnjava se da je tome tako dok se $41 \%$ ili 25 izjašnjava da to nije točno. Nastavno na anketno istraživanje, a koje nije bilo potrebno provoditi unutar ankete s obzirom na to da su točni i precizni podatci dostupni i prikazani na službenim web stranicama gradskih uprava izrađeni su grafovi. Iz dolje navedenih grafova vidljiv je postotak ženskih osoba u odnosu na muške osobe u gradskim upravama Vukovara, Vinkovaca, Otoka i Županje. U gradu Vinkovci postoji 9 upravnih odjela, grad Vukovar ima 6, dok u Županji postoje 3 upravna odjela isto kao i u Otoku. Jednostavnom analizom i uvidom u precizne podatke na web stranicama naveden je popis odjela i imena njihovih pročelnika/ica.

Prvi graf koji je prikazan, odnosno gradska uprava koja je analizirana je grad Vukovar. U grafu kako slijedi prikazan je postotak ženskih osoba u odnosu na muške u 6 upravnih odjela ovoga grada. Iz grafa je vidljivo da je postotak muškaraca $66 \%$ ili 4 pročelnika, a žena $33 \%$ ili 2 pročelnice.

\section{Slika 1. Upravna tijela grada Vukovara, 6 odjela}

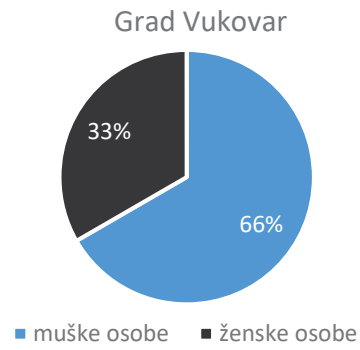

Izvor: vlastiti rad autora. Preuzeto s web stranice: https://www.vukovar.hr/gradska-uprava/ustrojstvo-grada (29.4.2021.) 
U daljnjem prikazu iznesen je graf grada Vinkovaca gdje postotak ženskih osoba kao pročelnica iznosi 4 ili 44\%, a muških osoba kao pročelnika ima 5 ili 56\% od ukupno 9 odijela.

Slika 2. Upravna tijela grada Vinkovaca, 9 odjela

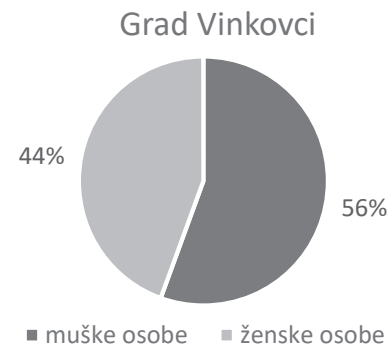

Izvor: vlastiti rad autora. Preuzeto s web stranice: https://grad-vinkovci.hr/hr/gradska-uprava (29.4.2021.)

Grada Županja ima 3 upravna odjela. Iz donjeg grafa je razvidno da sva tri odijela ili 100\% imaju muške pročelnike dok ženskih osoba kao pročelnica nema ili $0 \%$.

\section{Slika 3. Upravna tijela grada Županje, 3 odjela}

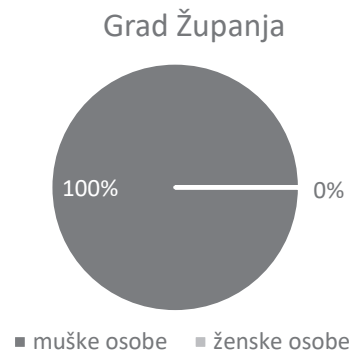

Izvor: vlastiti rad autora. Preuzeto s web stranice: https://www.zupanja.hr/index.php/kontakti (30.4.2021.)

Sljedeći prikaz je graf upravnih odjela grada Otoka, gdje je vidljivo da 2 odjela ili $66 \%$ rukovodi muška osoba dok 1 odjel ili 33\% rukovodi ženska osoba, pročelnica.

\section{Slika 4. Upravna tijela grada Otoka, 3 odjela}

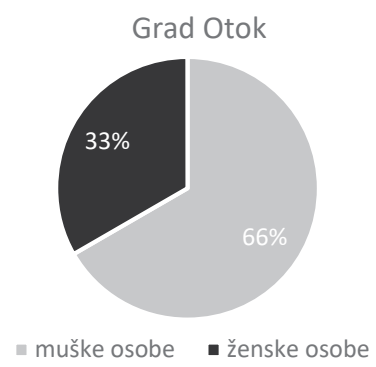

Izvor: vlastiti rad autora. Preuzeto s web stranice: https://www.otok.hr/category/grad-otok/gradska-uprava/ jedinstveni-upravni-odjel/ (30.4.2021.) 
Iz analize je razvidno da 21 gradski upravni odjel u odabranoj županiji ima 7 žena ili 33\% i 14 muškaraca ili 66\%. Gotovo u svim anketnim pitanjima i dodatnoj analizi iz službenih podataka gradova, dobiveni postotci kreću se u omjeru 2/3 pozitivnih rezultata u korist teze da "stakleni strop“, odnosno ženska spolna diskriminacija postoji kao barijera u odabranoj županiji točnije u svim gradskim upravama ove županije.

\section{ZAKLJUČAK}

Današnji nepredvidivi i izazovni trendovi na tržištu rada doživljavaju promjenu na gotovo tromjesečnoj razini. Ono što je vrijedilo prije tri mjeseca danas ne vrijedi, a pogotovo je teško predvidjeti što budućnost nosi u smislu ponude i potražnje na tržištu rada Republike Hrvatske. Tzv. „Covid 19“ vrijeme koje je ispred nas donosi nepredvidive, negativne učinke i traži od cjelokupnog društva brzu adaptaciju. Iz istraživanja ovoga rada koje je trebalo utvrditi razinu položaja žena na rukovodećim pozicijama u odabranoj Vukovarskoj - srijemskoj županiji razvidno je da su iste podzastupljene u gotovo svim gradovima ove županije. Podatak koji to navodi je postotak od samo 7 žena ili 33\% na rukovodećim funkcijama od ukupno 21 gradski upravni odjel. Ovakva neravnopravnost i društvena devijacija izražena je više na radnim mjestima u ruralnim sredinama gdje Hrvatsko patrijarhalno društvo dolazi do izražaja. Kroz provedeno istraživanje ostvaren je osnovni cilj rada, potvrđena je teza da je razina žena na rukovodećim pozicijama manja u odnosu na muškarce u odabranoj županiji. Postotak žena u odnosu na muškarce iz četiri prikaza grafa jasno govori o ženskoj podzastupljenosti na radnim mjestima pročelnika/ica. Iz dobivenih podataka ankete $u$ istraživanju utvrđene su i informacije o spolu te dobi ispitanika ili gradskih službenika. Metodom online ankete utvrđen je i dodatni cilj rada koji se odnosi na identificiranje problema i prepreka u napredovanju žena u lokalnoj samoupravi, odnosno u gradskim upravama. Dobivena je spoznaja iz mišljenja ispitanika o nemogućnost napredovanja osoba ženskog spola na rukovodećim funkcijama koja proizlazi iz nedovoljne uključenosti u lokalnu političku sferu što smatra čak $79 \%$ ili 47 ispitanika. Jedan od načina rješenja ovakvog problema je probiti nevidljivu barijeru ili „stakleni“ strop i u potpunosti ju odbaciti s javnom transparentnošću i otvorenosti gradskih uprava gdje bi se najbolji i najkvalificiraniji kandidat pozicionirao na rukovodeće mjesto ili mjesto pročelnika/ce. Na ovakav način bi se ispravila nejednakost u navedenim sustavima, ali ono što je važnije podigla bi se kvaliteta i učinkovitosti javnih usluga te brža i ekonomičnija provedba određenih aktivnosti lokalne zajednice. 


\title{
WOMEN IN MANAGEMENT POSITIONS IN A SELECTED COUNTY
}

\author{
Rudi Štekl, MSc, lecturer \\ European Business School Zagreb \\ 119 Selska cesta, 10110 Zagreb, Croatia \\ Phone: +385 914400 184, email: rudi.stekl@ebus.hr
}

\begin{abstract}
The position of women in managerial posts in the public and private sectors is becoming increasingly important in the labor market in the Republic of Croatia. The term "glass ceiling", used when talking about preventing the advancement of women to higher hierarchical levels in a given workplace, is gaining increasing representation as an important topic. The main goal of this paper is to show the level of position of women, i.e., their representation in local self-government units through research through a survey questionnaire on a sample of 60 city officials of a selected county. This model or the so-called "phenomenon of female gender discrimination" especially dominates in local and regional self-government units, where insufficient inclusion of women in the political spectrum consequently leads to poorer employment status and inability to advance professionally. Although the law on gender equality prohibits gender discrimination in the workplace, the "glass ceiling" still blocks the advancement of women to the highest positions in the system of local self-government units. Other goals of the paper are the identification of obstacles to the advancement of women on the organizational scale and the proposed recommendations for improving the career development of women in this system. The paper presents the findings of the results derived from the research. The role and importance of such issues in society is increasingly expressed precisely in the form of market needs and inclusion of the entire social spectrum. Society determines its future and the level of advancement at which everyone should have equal rights and opportunities regardless of gender, age and race!
\end{abstract}

Keywords: glass ceiling; position of women; local authority units 


\section{LITERATURA}

1. Avelini-Holjevac, I. i Galičić, V. (2005). Žene u poduzetništvu. In: Entrepreneurship and macroeconomic management

2. Deloitte, Deloitte SheXO klub, Zagreb (2013). Žene u poslovnom svijetu. Preuzeto s: https:// www2.deloitte.com/content/dam/Deloitte/hr/Documents/about-deloitte/hr_shexo_ zene_u_poslovnom_svijetu.pdf (13.04.2021.)

3. Jalšenjak, B. i Krkač K. (2016). Poslovna etika, korporacijska društvena odgovornosti i održivost

4. Leinert-Novosel, S. (2004). Policy of Women's Employment Croatian Political Science Review

5. Narodne novine (2017). Zakon o ravnopravnosti spolova (NN 82/08, 69/17). Preuzeto s: https:// www.zakon.hr/z/388/Zakon-o-ravnopravnosti-spolova (13.04.2021.)

6. Selectio.hr (2016). Značajan rast udjela žena u upravama vodećih hrvatskih tvrtki. Preuzeto s: https://www.selectio.hr/znacajan-rast-udjela-zena-u-upravama-vodecih-hrvatskih-tvrtki/ (14.04.2021.)

7. Vučemilović, V. (2011). Diskriminacija žena na tržištu rada s osvrtom na Hrvatsku

8. Vidaček-Hainš, V., Begičević-Ređep, N., Višnjić, N. (2018). Stavovi i percepcija žena na rukovodećim pozicijama o njihovom položaju na radnom mjestu 